\title{
EVALUATION OF GENOTOXICITY PROFILE OF JASADA BHASMA (A ZINC-BASED MINERAL FORMULATION) IN SWISS ALBINO MICE
}

\author{
RAVI BHASKAR ${ }^{1 *}$, MEGHA A DOSHI ${ }^{1}$, ANJANA $S^{2}$, RAVI M $^{3}$, NAVEEN KUMAR ${ }^{4}$, RAVI SHANKAR $B^{5}$, \\ SHAKUNTHALA R PAI ${ }^{6}$, SAVITHA HEMALATHA ${ }^{7}$
}

${ }^{1}$ Department of Anatomy, Krishna Institute of Medical Sciences Deemed University, Karad, Maharashtra, India. ${ }^{2}$ Department of Anatomy, Srinivas Institute of Medical Sciences and Research Centre, Mangaluru, Karnataka, India. ${ }^{3}$ Department of Pharmacology, Kodagu Institute of Medical Sciences, Kodagu, Karnataka, India. ${ }^{4}$ Department of Anatomy, Melaka Manipal Medical College, Manipal Academy of Higher Education, Manipal, Karnataka, India. ${ }^{5}$ SDM Research Centre for Ayurveda and Allied Sciences, Udupi, Karnataka, India. ${ }^{6}$ Department of Anatomy, Kanachur Institute of Medical Sciences, Mangaluru Karnataka, India. ${ }^{7}$ Department of Anaesthesia, Jayadeva Institute of Cardiovascular Sciences and Research, Bengaluru, Karnataka, India. Email: drravibhaskarr@gmail.com

Received: 29 September 2018, Revised and Accepted: 10 November 2018

ABSTRACT

Objective: Genotoxicity is regarded as one of the potential risk factors for causing pathological diseases. It was confirmed that many chemicals have the mutagenic activity which leads to cancer. A compound which interacts with genetic material DNA and shows adverse effects by altering its structure or function is referred to as genotoxic.

Aim of the Study: The present research was mainly focused to evaluate genotoxicity profile of classically prepared Jasada Bhasma (JB) by employing three crucial genotoxic testing protocols.

Methods: The present study involved 40 Swiss albino mice weighing between 25 and $30 \mathrm{~g}$ body weights categorized into four different groups. Group-I (normal control) received $0.5 \%$ carboxymethyl cellulose as vehicle. Group-II (toxicant control) received $40 \mathrm{mg} / \mathrm{kg} / \mathrm{body}$ weight cyclophosphamide on the $28^{\text {th }}$ day. Group-III and IV received test drug JB $15.6 \mathrm{mg} / \mathrm{kg}$ and $78 \mathrm{mg} / \mathrm{kg}$, respectively, for 28 consecutive days. Blood samples were collected and processed for evaluating by comet assay. The animals were sacrificed and collected the bone marrow from both the femur for chromosomal aberration and micronuclei assay.

Results: JB administered at two different dose levels did not show any significant changes in the comet assay parameters, no micronucleus was found and did not produce any chromosomal aberrations both numerically and structurally when compared to positive test control group.

Conclusion: The genotoxicity evaluation of JB did not show any chromosomal aberrations and presence of micronucleus. Thus, the safety data will refine therapeutic utility of JB encouraging their rationale use and translate into greater and broader utilization of JB.

Keywords: Jasada Bhasma, Genotoxicity, Comet assay, Chromosomal aberrations.

(c) 2019 The Authors. Published by Innovare Academic Sciences Pvt Ltd. This is an open access article under the CC BY license (http://creativecommons. org/licenses/by/4. 0/) DOI: http://dx.doi.org/10.22159/ajpcr.2019.v12i1.29965

\section{INTRODUCTION}

Zinc is considered as fourth most consumed metal after iron, aluminum, and copper. Besides, its widespread use in the industries, it also used in health-care products. It is considered an essential trace element and in the human growth and development, immunity, and neuronal development, zinc has an important role. An adult human body contains $2-3 \mathrm{~g}$ of zinc. The essential dietary sources are oysters, beef, and peanuts $[1,2]$. Zinc is used in Indian traditional systems of medicine, especially Ayurveda in the form of Bhasma. Bhasmas are the ash preparations. They are inorganic preparations produced by metals or minerals made into $200-300 \mathrm{~nm}$ sized particles by conversion into its compounds such as carbonates and oxides prepared by the traditional method [3,4]. Jasada Bhasma (JB) is one of the mineral based ash formulations. It is highly absorbable due to the decreased particle size. It has many therapeutic indications such as immune-modulatory, as a supplement in zinc deficiency, and as anti-inflammatory, anti-pyretic, antidiabetic, hematinic, and hematogenic agent [5].

According to some experts, there is a need to provide an experimental basis for their safety and efficacy. In this background, some studies have been done to assess them for toxicity. However, there are a few informative data related to the effect at the genetic level. In this study, zinc-based JB was assessed for potential genotoxicity considering its wide use for the treatment of diseases such as diabetes, anemia, ophthalmic disorders, cough, ulcers, and skin diseases [6-10]. A chemical which interacts with genetic material DNA and shows adverse effects by altering its structure or function is referred to as genotoxic. Most of the drugs are genotoxins and produce an irreversible impact on the genetic map. Mutagenicity studies by in vivo tests in mammals with a close resemblance of metabolism to humans have been reported [11-13]. The standard laboratory tests available for genotoxicity evaluation are bacterial reverse mutation test (Ames Test), sex-linked recessive lethal test in Drosophila melanogaster, Escherichia coli, reverse assay, in vitro mammalian chromosome aberration test, in vitro mammalian cell gene mutation test, mammalian erythrocyte micronucleus test, mammalian bone marrow chromosome aberration test, rodent dominant harmful lest, in vitro sister chromatid exchange assay in mammalian cells, Saccharomyces cerevisiae, and gene mutation assay [14].

The present study was mainly focused to evaluate genotoxicity profile of classically prepared JB by employing three important genotoxic testing protocols such as chromosomal aberrations, micronuclear assay, and comet assay in Swiss albino mice.

\section{METHODS}

The present experimental study was performed using 40 Swiss albino mice of both sexes which were obtained from animal house attached to 
Pharmacology and Toxicology Laboratory at SDM Centre for research in Ayurveda and Allied Sciences Udupi, India. The animals were acclimatized to standard laboratory conditions such as the temperature at $25^{\circ} \mathrm{C} \pm 2^{\circ} \mathrm{C}$, humidity of $50-55 \%$, and natural light and dark cycles for 7 consecutive days before experimentation. Animals were fed with commercial pellet diet (Pranav Agro-Industry, Pune) and water ad libitum. Institutional Animal Ethical Committee clearance certificate was obtained before the experimentation SDMCA/IAEC/CPCEA/ GI04/2011.

\section{Test drug}

JB (zinc-based formulation) was used to evaluate the genotoxicity potential. Test drug was obtained from a renowned expert in Rasashastra (a specialized branch of Ayurveda). The study material was obtained from Sri Siddeshwara drugs, Cherpulassery, Palakkad, Kerala, batch number of JB drug September 33, 2012.

\section{Experimental design}

The study was designed for 28 days with Swiss albino mice weighing between 25 and $30 \mathrm{~g}$ body weights. Animals were divided into four different groups containing 10 mice each. Group-I considered as a normal control group and received $0.5 \%$ carboxymethyl cellulose as a vehicle (CMC). Group-II considered as toxicant control which received on the $28^{\text {th }}$ day $40 \mathrm{mg} / \mathrm{kg} /$ body weight cyclophosphamide. Group-III and IV received test drug JB $15.6 \mathrm{mg} / \mathrm{kg}$ and $78 \mathrm{mg} / \mathrm{kg}$, respectively, for 28 consecutive days.

\section{Dose selection}

Dose was derived from human therapeutic dose (TED) by standard dose conversion method based on the body surface area ratio proposed by Paget and Burns 1969 [10]. Human dose is $120 \mathrm{mg} / \mathrm{kg} / \mathrm{body}$ weight. Two ranges of dose level were selected, TED, and 5 times of TED $\times 5$. On this basis, TED was calculated as $15.6 \mathrm{mg} / \mathrm{kg} /$ body weight (TED) and $78 \mathrm{mg} / \mathrm{kg} /$ body weight for 5 times of TED $\times 5$. JB suspension was made in $0.5 \%$ of CMC and orally administered to animals with the help of an oral catheter.

Test drug JB was administered for 28 consecutive days. On the $28^{\text {th }}$-day positive control group (Group-II) is received cyclophosphamide at a dose of $40 \mathrm{mg} / \mathrm{kg}$ by intraperitoneal injection. On $29^{\text {th }}$-day blood samples were collected into heparinized tubes from orbital plexus under mild ether anesthesia from all the groups. Peripheral blood samples were processed for evaluating by comet assay $[8,11,15,16]$. On the $29^{\text {th }}$ day, after blood was withdrawn from five mice from each group, which were injected with colchicine ( $4 \mathrm{mg} / \mathrm{kg} \mathrm{IP}$ ) to arrest the cells into metaphase stage. These animals were sacrificed to collect bone marrow from both the femur for chromosomal aberration test. Moreover, rest of the animals were also slaughtered and bone marrow harvested for micronuclei assay.

\section{Alkaline (ph>13) comet assay}

The alkaline $(\mathrm{pH}>13)$ comet assay and was carried out according to Burlinson et al., 2007, and Hartmann et al., 2003 [8,11]. Briefly, a $10 \mu \mathrm{L}$ aliquot of the suspension containing approximately 10,000 cells was mixed with $0.5 \%$ low melting point agarose (Sigma) and spread on standard microscope slides which were pre-dipped in agarose. On the cold surface, the slides were allowed to harden. All the slides were placed in cold lysis solution $(2.5 \mathrm{M} \mathrm{NaCl}, 100 \mathrm{mM}$ ethylenediaminetetraacetic acid [EDTA], and $10 \mathrm{mM}$ Trizma base, with $1 \%$ Triton X-100 (Sigma), and $10 \%$ dimethyl sulfoxide). Following at least $1-2 \mathrm{~h}$ of incubation in lysing solution, two slides per sample was rinsed with $0.4 \mathrm{M}$ Trizma base and incubated in alkaline conditions $(300 \mathrm{mM} \mathrm{NaOH}, 1 \mathrm{mM}$ EDTA, $\mathrm{pH}>13$ ) for $20 \mathrm{~min}$, followed by electrophoresis in the same buffer for $30 \mathrm{~min}$ at $0.7 \mathrm{~V} / \mathrm{cm}$ (electrode to electrode) and $300 \mathrm{~mA}$ current. After electrophoresis to neutralize the alkali, slides were immersed in an excess amount of $0.4 \mathrm{M}$ Trizma base and then fixed in 100\% ethanol. After fixation, the slides were air dried then stained with ethidium bromide. The slides were scored without knowledge of the dose group. The extent of DNA migration was determined for each sample by simultaneous image capture and scoring of 100 cells (50 cells on each of two slides) at $\times 200$ magnifications using an imaging system with comet assay software. The extent of DNA migration for all samples was evaluated according to the following endpoint measurements such as percentage tail DNA, tail length, and olive tail moment.

\section{Micronucleus assay}

It was carried out by the method suggested by Witt et al., 2008 [15]. The bone marrow was aspirated from the shaft of femurs into $5 \%$ bovine serum albumin (BSA) using 25 gauge needle. The homogeneous suspension was made and centrifuged at $1000 \mathrm{rpm}$ for $5 \mathrm{~min}$. The supernatant was removed after the centrifugation. With $0.5 \mathrm{ml}$ of $5 \% \mathrm{BSA}$, the sediment was mixed thoroughly and smeared on a clean slide. Air dried the prepared slides and fixed for $5 \mathrm{~min}$ in absolute methanol. The air-dried smears were first stained with 1:1 diluted May-Grunwald stain using phosphate buffer of $\mathrm{pH} 6.8$ for $15 \mathrm{~min}$. Then, the slides were transferred to Giemsa stain diluted with phosphate buffer for $10 \mathrm{~min}$. Moreover, slides were washed in buffer solution for $5 \mathrm{~min}$. Air-dried slides were observed under 100X oil immersion objective to score the micronucleated polychromatic erythrocytes and micronucleated normochromatic erythrocytes. About 1000 polychromatic erythrocyte (PCE) and the corresponding number of normochromatic erythrocyte (NCE) scored for the presence of micronuclei and the determination of PCE/NCE ratio. These ratios were used as a measure of the toxicity of test materials. Statistical analysis was done to find out the significance of micronucleus induction.

\section{Chromosomal aberration test}

It was carried out in bone marrow cells by the method suggested by Hayashi, 1992 [16]. Bone marrow cells from both femurs were collected and subjected to hypotonic shock ( $\mathrm{KCl} 0.075 \mathrm{M}$ ) for about $20 \mathrm{~min}$ at room temperature. The suspension was centrifuged at $1000 \mathrm{rpm}$ for $8 \mathrm{~min}$. The cells were fixed with the freshly prepared methanol-acetic acid (3:1) fixative for $45 \mathrm{~min}$ at room temperature and centrifuged at $1000 \mathrm{rpm}$ for $8 \mathrm{~min}$. Again the cells were re-suspended in fresh fixative for $10 \mathrm{~min}$ and centrifuged for $8 \mathrm{~min}$ at $1000 \mathrm{rpm}$. The procedure was repeated for 2-3 times. Finally, $0.5 \mathrm{ml}$ of the suspension was prepared using fresh fixative. Two to three drops of cell suspension were dropped from a distance using Pasteur's pipette on a clean prechilled glass slide and were dried on the hot plate at $40^{\circ} \mathrm{C}$. Then, the slides were air dried at room temperature and finally stained with a $5 \%$ dilution of Giemsa stain in phosphate buffer ( $\mathrm{pH}$ 6.8) for 30 min. The chromosomes of 1000 cells in metaphase were analyzed with a $\times 100$ oil immersion objective, using a trinocular microscope. Metaphases with chromosomes, chromatid breaks, gaps, rings, stickiness, centric fusion, and deletion were recorded.

\section{Statistical analysis}

The data were collected and expressed as mean \pm SEM and analyzed by one-way ANOVA followed by Dunnett's multiple tests using GraphPad InStat version 3.5. $\mathrm{p}<0.05$ was considered statistically significant.

\section{RESULTS}

Genotoxic potential of JB analyzed by alkaline (ph>13) comet assay Cyclophosphamide $(40 \mathrm{mg} / \mathrm{kg}$ ) dose caused significant damage to the genetic material by significant increase in the parameters, such as comet length, comet height, comet tail length, percentage DNA, tail movement, and olive moment as compared to standard control $(\mathrm{p}<0.01)$. JB administered for 28 consecutive days at two different dose levels did not show any significant changes in these parameters, such as comet length, comet height, comet tail length, percentage DNA, tail movement, and olive moment and values are comparable with that of normal control (Table 1 and Fig. 1).

\section{Micronuclei assay}

There was a significant increase in the number of micronuclei (MNi) in the cyclophosphamide group as compared to normal control $(\mathrm{p}<0.01)$. The micronucleus was not found at the two dose levels of JB as compared cyclophosphamide group, and micronucleus assay did not reveal any statistically significant difference between the groups (Table 2 and Fig. 2). 
Table 1: Effect of JB on DNA damage in comet assay

\begin{tabular}{lllll}
\hline Parameters & Normal control $\mathbf{( m g} / \mathbf{k g})$ & Positive control $\mathbf{( m g} / \mathbf{k g})$ & JB $\mathbf{1 5 . 6} \mathbf{~ m g} / \mathbf{k g}$ & JB \\
\hline Comet length & $132 \pm 12.98$ & $233.0 \pm 12.97^{* *}$ & $182.38 \pm 25.63$ & $104.77 \pm 3.15$ \\
Comet height & $113 \pm 10.94$ & $180.08 \pm 9.39^{* *}$ & $154 \pm 22.04$ & $106.69 \pm 4.13$ \\
Comet tail length & $1.71 \pm 0.42$ & $18.75 \pm 5.84^{* *}$ & $2.91 \pm 0.84$ & $6.83 \pm 2.19$ \\
\% DNA & $0.82 \pm 0.31$ & $22.30 \pm 4.64^{* *}$ & $5.45 \pm 1.41$ & $10.71 \pm 3.87$ \\
Tail movement & $0.0022 \pm 0016$ & $6.36 \pm 2.15^{* *}$ & $0.93 \pm 0.64$ & $2.55 \pm 1.26$ \\
Olive movement & $7.30 \pm 2.18$ & $19.31 \pm 2.04^{*}$ & $6.12 \pm 2.24$ & $4.21 \pm 1.38$ \\
\hline
\end{tabular}

Table 2: Effect of JB on bone marrow cells in micronuclear test

\begin{tabular}{ll}
\hline Group & MNPCEs/2000 PCEs \\
\hline Normal control & $1.16 \pm 0.65$ \\
Cyclophosphamide $(40 \mathrm{mg} / \mathrm{kg})$ & $60.66 \pm 6.86^{* *}$ \\
JB 15.6 mg/kg & $1.66 \pm 0.33$ \\
JB 78 mg/kg & $1.83 \pm 0.30$ \\
\hline
\end{tabular}

Data expressed in mean \pm SEM. ${ }^{*} \mathrm{p}<0.05,{ }^{* *} \mathrm{p}<0.01$ in comparison

to normal control. MNPCEs: Micronucleated polychromatic

erythrocytes, PCE: Polychromatic erythrocyte, JB: Jasada Bhasma
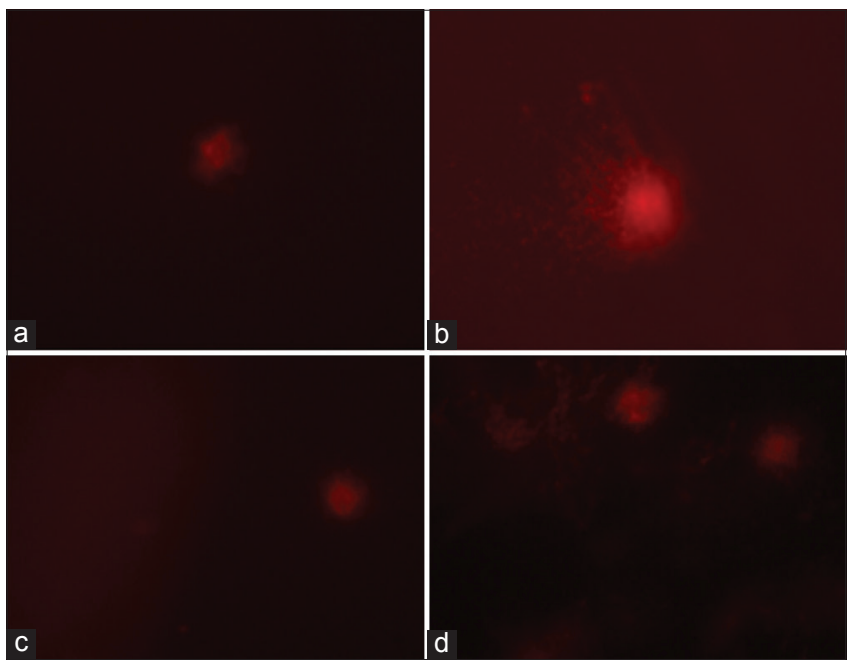

Fig. 1: Photomicrograph of comet assay. (a) NC - normal control,

(b) CYP - cyclophosphamide, (c) JB (TED) - Jasada Bhasma therapeutic dose (TED), and (d) JB (TED ×5) - Jasada Bhasma 5 times of TED

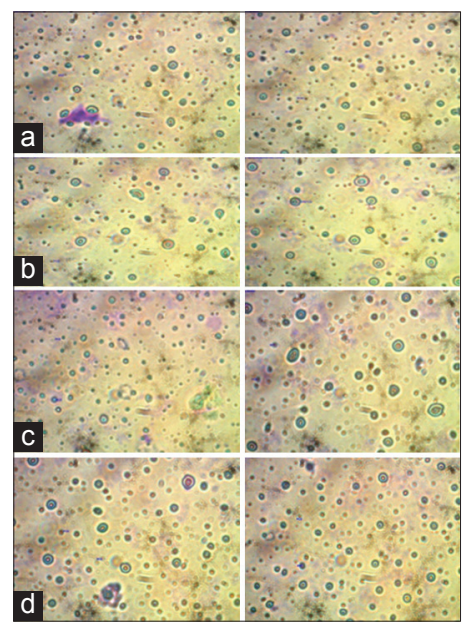

Fig. 2: Photomicrograph of micronucleus assay in bone marrow cell smear. (a) NC - normal control, (b) CYP -cyclophosphamide control, (c) JB (TED) - Jasada Bhasma therapeutic dose (TED), and (d) JB (TED ×5) - Jasada Bhasma 5 times of TED

\section{Chromosomal aberration assay}

The bone marrow cells were arrested in the metaphase stage and microscopically examined for both numerical and structural chromosomal aberrations such as chromosomal gap, chromatid gap, exchange, fragments, pulverization, ring, and deletion. It is observed that repeated administration of JB at both therapeutic and 5 times of dose levels did not produce any chromosomal aberrations both numerically and structurally (Table 3 and Fig. 3 ).

\section{DISCUSSION}

Genotoxicity is considered to be one of the potential risk factors for causing diseases such as cancer, cardiovascular, aging-related disorders, cystic fibrosis, sickle cell anemia, and diabetes. The incidence of genotoxicity and mutagenicity is prevailing high in recent years due to industrialization, exposure to agricultural pesticides and a wide range of chemical substances and radiations. Thus, the regulatory authorities have made it mandatory to test any substances for its safety profile including genotoxicity and mutagenicity. In the present study, a battery of tests such as comet assay, chromosomal aberration tests, and micronucleus assay was conducted to evaluate the genotoxicity potential of JB.

The toxicant materials cause genotoxicity by direct interaction with the genetic materials such as DNA or RNA. This interaction might be either with single nucleotide base or a particular location on the DNA structure. DNA damage can be assessed based on a number of breakings, lesions, fusions, deletions, or mis-segregations in intact DNA. It may lead to mutagenesis and causes different malignancies. Oxidative stress also plays an important role in the genotoxicity. During the normal cellular metabolism, that is, mitochondrial respiratory activity, certain amounts of oxidative free radicals are produced, which are effectively managed or detoxified by either endogenous or dietary antioxidants. However, in case of any chronic or acute exposure to certain cytotoxic or noxious chemicals, the endogenous antioxidant fails to detoxify. It results in the generation of the enormous amount of reactive oxygen species (ROS) such as $\mathrm{O}_{2}, \mathrm{OH}-$, and $\mathrm{H}_{2} \mathrm{O}_{2}$. ROS can cause severe oxidative lesions in DNA and form 8- hydroxyl deoxyguanosine, which is a potent mutagenic lesion $[17,18]$. Along with genetic material, it can also denature biologically essential lipids and protein molecules and leads to degenerative diseases such as atherosclerosis, neurodegenerative disorders, and cystic fibrosis. Zinc considered being one of the essential trace elements, and it is safer only at lower doses; however, it can exert system toxicity at higher doses, mainly by deposit in neuronal tissues of the brain, and slowly causes cellular damage [19]. The long-term use or acute intoxication of zinc interferes with the absorption of copper, and hence many of the toxic symptoms are due to copper deficiency in the body. It also plays an important role in the cellular apoptosis by interfering with the molecular regulators of programmed cell death [20]. A study report reveals a boy who has developed lethargy and focal neurological deficits after 3 days of $12 \mathrm{~g}$ of metallic zinc ingestion [21]. It has been reported that the zinc oxide nanoparticle exerts dose-dependant genotoxicity and cytotoxicity [22].

Comet assay or single cell gel electrophoresis is a simple, inexpensive, and more sensitive technique used in the analysis of DNA damage. It has wide applications in testing genotoxic potentials of large-scale pharmaceutical products, agriculture pesticides, and industrial 
Table 3: Effect of JB on chromosomal aberration

\begin{tabular}{|c|c|c|c|c|c|c|c|c|c|}
\hline Group & & & ChI & & Ex & Fg & PS & $\mathbf{R}$ & DL \\
\hline Normal control & - & - & - & - & - & - & - & - & - \\
\hline Cyclophosphamide control & + & + & + & + & - & + & - & - & + \\
\hline JB 15.6 m/kg & - & - & - & - & - & - & - & - & - \\
\hline $\mathrm{JB} 78 \mathrm{mg} / \mathrm{kg}$ & - & - & - & - & - & - & - & - & - \\
\hline
\end{tabular}

Ex: Exchange, Fg: Fragments, PS: Pulverization, R: Ring, DL: Deletion, JB: Jasada Bhasma

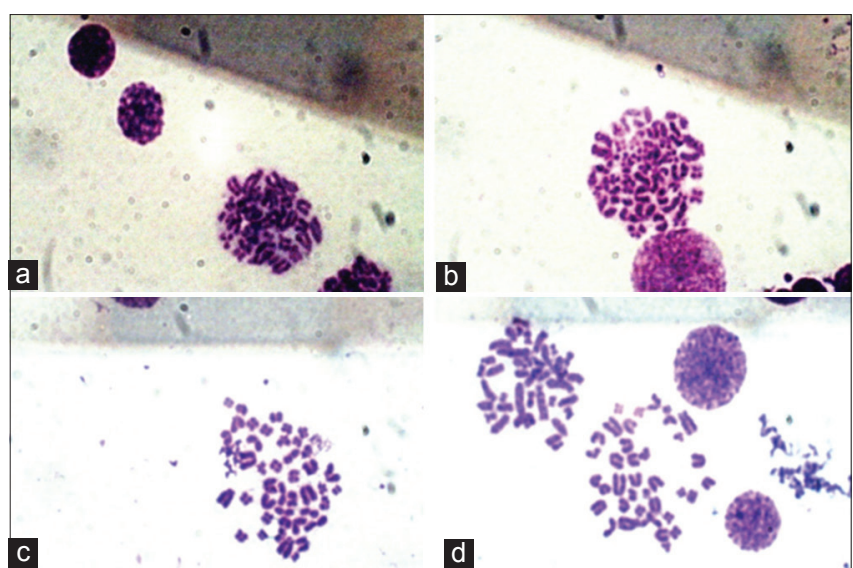

Fig. 3: Photomicrograph of chromosomal aberration test,

(a) Jasada Bhasma (TED) - Jasada Bhasma therapeutic dose (TED), (b) Jasada Bhasma (TED ×5) - Jasada Bhasma 5 times of TED

chemicals [23]. The single or double strand DNA damage is confirmed by fragmented DNA migrated out of the cells nucleolus in the form of a characteristic streak similar to the tail of a comet [24]. In the present study, the cyclophosphamide drug-treated rat samples showed a significant increase in the comet length, comet height, comet tail length, percentage DNA, tail movement, and olive movement as compared to normal control. The JB treated groups at both dose levels showed no significant changes in the comet assay parameters as compared to cyclophosphamide group. The changes in DNA profile were almost the same as that of normal control, indicating it has no interference action with the DNA at both dose levels. Cyclophosphamide is a well-known genotoxic and cytotoxic agent. It causes genotoxicity by producing highly reactive carbonium ion intermediates which transfer the alkyl group to cellular macromolecules. The alkylation results in cross-linking or abnormal base pairing or scission of DNA strand. Thus, the damaged DNA fragments can be seen as the tail of a comet. The micronuclear assay is based on scoring the MNi present in the treated cells [25]. Micronuclei are formed during anaphase from chromosomal fragments or whole chromosomes that are left behind when the nucleus divides. In the current study, administration of cyclophosphamide caused a significant increase in the $\mathrm{MNi}$ as compared to normal control. Repeated administration of JB did not cause any substantial changes in the MNi formation as compared to cyclophosphamide group. This shows JB at both dose levels does not have the potential to induce chromosomal breakage or chromosomal gain or loss in bone marrow cells. The purpose of the chromosome aberration test is to identify the agents or substances which can cause structural mutations in chromosomes or chromatids [26,27]. The chromosomal changes such as polyploidy and duplication can also be assessed by this test. Thus, any positive test result shows test substance possesses potential mutagenic or carcinogenic action in the biological system [28]. In the present study, the cyclophosphamide administration showed chromosomal and chromatid breaks, gaps, and deletions as compared to normal control group, whereas there were no changes in the chromosomal and chromatid material in the JB administered group as compared to cyclophosphamide group. Thus, the test drug has no potential role to cause chromosomal aberration when administered at both dose levels.

\section{CONCLUSION}

Despite its extensive use, the genotoxicity profile of JB is unexplored. In this regard evaluating the genotoxic potential of JB provided experimental proof for its safety. In the present study, the genotoxicity of JB was assessed by comet assay, micronuclei, and chromosomal aberration tests. Results show normal intact DNA and chromosomal structure. Thus, providing safety data will refine therapeutic utility of JB encouraging their rationale use and translate into higher and broader utilization of JB.

\section{ACKNOWLEDGMENT}

The authors are highly grateful to Director and Dean, Krishna Institute of Medical Sciences Deemed University, Karad, Maharashtra, India, for their constant motivation to carry out this research work. The authors thank revered Sri. CA.A. Raghavendra Rao President of Srinivas Institute of Medical Sciences and Research Centre, Mangaluru, Karnataka, India, for his constant support.

\section{AUTHOR'S CONTRIBUTION}

Ravi Bhaskar carried out the study and was the charge of overall performance and planning. Megha Doshi, Shakunthala R Pai and Ravishankar S have designed and supervised the study. Naveen Kumar and Anjana $\mathrm{S}$ are responsible for the integrity and accuracy of the data analysis and histological techniques. Ravi M is responsible for study concept and manuscript draft. Savitha Hemalatha is responsible for data analysis and critical revision.

\section{CONFLICTS OF INTEREST}

The authors declare that the research was conducted in the absence of any commercial or financial relationships that could be construed as a potential conflicts of interest.

\section{REFERENCES}

1. Laura MP, Lohar R, Hajo H. The essential toxin: Impact of zinc on human health. Int J Environ Res Public Health 2010;7:1342-65.

2. Osman IF, Baumqarner A, Cemeli E, Fletcher JN, Anderson D. Genotoxicity and cytotoxicity of zinc oxide and titanium dioxide in hep-2 cells. Nanomedicine 2010;5:1193-203.

3. Priyavarat S. Kaiyyadeva Nigantu-Pathya Vibodhaka. $1^{\text {st }}$ ed. Varanasi: Chaukhamba Orientalia; 1979. p. 703.

4. Priyavarat S. Kaiyyadeva Nigantu-Pathya Vibodhaka. $1^{\text {st }}$ ed. Varanasi: Chaukhamba Orientalia; 1979. p. 696.

5. O' Dell BL, Sunde RA. Handbook of Nutritionally Essential Mineral Elements. New York: Marcel Dekkar Inc.; 1997. p. 680.

6. Dev S. Ancient-modern concordance in ayurvedic plants: Some examples. Environ Health Perspect 1999;107:783-9.

7. Doshi M, Bhaskar R, Anjana S, Ravi M, Satheesha KS, Ravishankar B, et al. Evaluation of genotoxicity profile of tamra bhasma (A copperbased metallic preparation) in Swiss albino mice. Int J Anat Radiol Surg 2018;12:1-4

8. Burlinson B, Tice RR, Speit G, Agurell E, Brendler-Schwaab SY, Collins AR, et al. Fourth international workgroup on genotoxicity testing: Results of the in vivo comet assay workgroup. Mutat Res 2007;627:31-5.

9. Mohamed S, Sabita U, Rajendra S, Raman D. Genotoxicity: Mechanisms, testing guidelines, and methods. Glob J Pharm Sci 2017; 1:555-75.

10. Paget GE, Barnes JM. In: Lawrence DR, Bacharach AL, editors. Evaluation of Drug Activities: Pharmacometrics. New York: Academic 
Press; 1964. p. 161.

11. Hartmann A, Agurell E, Beevers C, Brendler-Schwaab S, Burlinson B, Clay P, et al. Recommendations for conducting the in vivo alkaline comet assay $4^{\text {th }}$ international comet assay workshop. Mutagenesis 2003;18:45-51.

12. Allen E. Reactions of the genital tissues to estrogens. Cold Spring Harb Symp Quant Biol 1937;5:104-10. Fraser IE. The use of colchicine and colcemid for metaphase stasis in the matrix cells of wool follicles. Aust J Biol Sci 1962;16:211-7.

13. Jackson MA, Stack HF, Waters MD. Genetic activity profiles of anticancer drugs. Mutat Res 1996;355:171-208.

14. Anderson D, Bishop JB, Garner RC, Otrosky-Wegman P, Selby PB. Cyclophosphmide: Review of its mutagenecity for an assessment of potential germ cell risks. Mutat Res 1995;330:115-81.

15. Witt KL, Livanos E, Kissling GE, Torous DK, Caspary W, Tice RR. Comparison of flow cytometry-and microscopy-based methods for measuring micronucleated reticulocyte frequencies in rodents treated with non-genotoxic and genotoxic chemicals. Mutat Res 2008;649:101-3

16. Hayashi M. The micronucleus test most widely used in vivo genotoxicity test. Genes Environ 2016;38:18.

17. Karihtala P, Soini Y, Vaskivuo L, Bloigu R, Puistola U. DNA adduct 8-hydroxydeoxyguanosine, a novel putative marker of prognostic significance in ovarian carcinoma. Int J Gynecol Cancer 2009;19:1047-51.

18. ValavanidisA, Vlachogianni T, Fiotakis C. 8-hydroxy-2 -deoxyguanosine (8-OHdG): A critical biomarker of oxidative stress and carcinogenesis.
J Environ Sci Health C 2009;27:120-39.

19. Fosmire GJ. Zinc toxicity. Am J Clin Nutr 1990;51:225-7.

20. Kim YH, Kim EY, Gwag BJ, Sohn S, Koh JY. Zinc-induced cortical neuronal death with features of apoptosis and necrosis: Mediation by free radicals. Neuroscience 1999;89:175-82.

21. Murphy JV. Intoxication following ingestion of elemental zinc. JAMA 1970;212:2119-20

22. Powell MC, Kanarek MS. Nanomaterial health effects-part 1: Background and current knowledge. Wis Med J 2006;105:16-20.

23. Hartmann A, Agurell E, Beevers C, Brendler SS, Burlinson B. Recommendations for conducting the in-vivo alkaline comet assay. Mutagenesis 2003;18:45-51.

24. Fenech M, Kirsch VM, Natarajan AT, Surralles J, Crott J. Molecular mechanisms of micronucleus, nucleoplasmic bridge and nuclear bud formation in mammalian and human cells. Mutagenesis 2011;26:125-32.

25. Fenech M. Cytokinesis-block micronucleus cytome assay. Nat Protoc 2007:2:1084-104.

26. Anderson D, Plewa MJ. The international comet assay workshop. Mutagenesis 1998;13:67-73.

27. Huang Y, Chang CC, Trosko JE. Aphidicolin-induced endoreduplication in Chinese hamster cells. Cancer Res 1983;43:1362-4.

28. Locke HC. Endoreduplication in Chinese hamster cells during alpharadiation induced G2 arrest. Mutation Res 1983;119:403-13 